\title{
CAN EXERCISE MAKE OUR CHILDREN SMARTER?
}

\author{
Nenad STOJILJKOVIĆ ${ }^{1}$, Petar MITIĆ ${ }^{1}$, Goran SPORIŠ ${ }^{2}$ \\ ${ }^{1}$ University of Niš, Faculty of Sport and Physical Education, Niš, Serbia \\ ${ }^{2}$ University of Zagreb, Faculty of Kinesiology, Zagreb, Croatia \\ Corresponding Author: \\ Nenad STOJILJKOVIĆ, PhD \\ University of Niš, Faculty of Sport and Physical Education, \\ Čarnojevića 10a, 18000 Niš, Serbia \\ Phone: +381638084961 \\ e-mail: snesadif@yahoo.com
}

\section{ABSTRACT}

Purpose. The aim of this study is to reveal the effects of exercise on the brain structure and function in children, and to analyze methodological approach applied in the researches of this topic.

Methods. This literature review provides an overview of important findings in this fast-growing research domain. Results from cross-sectional, longitudinal, and interventional studies of the influence of exercise on the brain structure and function of healthy children are reviewed and discussed.

Results. The majority of researches are done as cross-sectional studies based on the exploring correlation between the level of physical activity and characteristics of brain structure and function. Results of the studies indicate that exercise has positive correlation with improved cognition and beneficial changes to brain function in children. Physically active children have greater white matter integrity in several white matter tracts (corpus callosum, corona radiata, and superior longitudinal fasciculus), have greater volume of gray matter in the hippocampus and basal ganglia than their physically inactive counterparts. The longitudinal/interventional studies also showed that exercise (mainly aerobic) improve cognitive performance of children and causes changes observed on functional magnetic resonance imaging scans (fMRI) located in prefrontal and parietal regions.

Conclusion. Previous researches undoubtable proved that exercise can make positive changes of the brain structures in children, specifically the volume of the hippocampus which is the center of learning and memory. Finally, the researchers agree that 
Nenad STOJILJKOVIĆ, Petar MITIĆ, Goran SPORIŠ: CAN EXERCISE MAKE OUR CHILDREN SMARTER? ..., 115-127

the most influential type of exercise on changes of brain structure and functions are the aerobic exercises.

Keywords: physical activity, cognition, brain, children.

\section{LAHKO OTROCI Z VADBO POSTANEJO PAMETNEJŠI?}

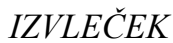

Namen: Namen te študije je razkriti učinke telesne vadbe na možgansko strukturo in delovanje pri otrocih ter analizirati metodološki pristop, uporabljen v raziskavah $s$ tega področja.

Metode: S pregledom literature smo izpostavili pomembne ugotovitve na tem hitro rastočem področju raziskav. Obravnavali smo rezultate intersekcionalnih, longitudinalnih in intervencijskih študij vpliva vadbe na možgansko strukturo in delovanje zdravih otrok.

Rezultati: Večina raziskav je izvedenih kot intersekcionalne študije, ki temeljijo na raziskovanju povezanosti med telesno aktivnostjo in značilnostmi možganske strukture in funkcije. Rezultati študij kažejo, da je telesna vadba pozitivno povezana z izboljšano kognicijo in koristno vpliva na spremembe delovanja možganov pri otrocih. Fizično aktivni otroci imajo povečano aktivnost bele snovi v več traktih bele snovi (corpus callosum, corona radiata in zgornji vzdolžni fascikul), imajo tudi več sive snovi v hipokampusu in bazalnih ganglijih kot otroci, ki so fizično neaktivni. Longitudinalne / intervencijske študije so pokazale tudi, da vadba (predvsem aerobna) izboljša kognitivno delovanje otrok in povzroči spremembe v prefrontalnem in parietalnem področju, ki se jih opazi pri slikanju z magnetno resonanco (fMRI).

Zaključki: Predhodne raziskave so nesporno dokazale, da lahko telesna vadba pozitivno spremeni možganske strukture pri otrocih, zlasti volumen hipokampusa, ki je središče učenja in spomina. Raziskovalci se strinjajo, da imajo aerobne vaje največji vpliv na spremembe možganskih struktur in funkcij.

Ključne besede: gibalna/športna aktivnost, kognicija, možgani, otroci 


\section{INTRODUCTION}

Physical activity of children has benefits not only to physical health and fitness but to cognitive and brain health as well. Many studies suggest that exercise can increase the brain volume of the children, make positive changes in structure and function of brain, improve their cognitive abilities and academic achievements (Hillman et al., 2009). Further research of relation between physical activity and brain is a very prospective area that could give one a new dimension in the studies of exercise and training. Having acquired strong scientific evidences of the influences of exercise and physical activities on the brain of children we can envisage a new approach in creating physical education curriculums aimed to develop not only physical abilities but also their cognitive side. The greatest influence of physical exercise has been observed in the domain of executive functions, which are of the great importance for performing daily activities, for the ability to adapt behavior in children, their intellectual functioning and success in performing tasks at school (Tomporowski, McCullick, Pendleton, \& Pesce, 2015). Exercise has beneficial effects for the mind, it increases attention and cognitive control, it improves emotional responsivity, it enhances short and long-term memory (Chaddock, Pontifex, Hillman, \& Kramer, 2011; Hillman, Erickson, \& Kramer, 2008). These functional improvements have a strong neurophysiological foundation based on the process of neuronal growth or neurogenesis (Kobilo et al., 2011). It is obvious that the brain is not a static but a very dynamic organ designed to change in response to experience. This ability of the brain to change his structure and function across the lifespan is known as neuroplasticity. Neuroplasticity of brain as the characteristic of adaptation and modification of brain structures in accordance to requirements of environment and some physical activities is very important (Myer et al., 2015). Brain cortex is especially susceptible to such requirements and responsible for the neuroplastic adaptations. The process of neuroplasticity can be explained by the rule that "neurons that fire together wire together" which means that frequent joined firing of neighboring neural cells leads to strengthening and preserving the synapses (Mundkur, 2005).

The major effects of exercise occur within two regions of brain: subventricular zone of the lateral ventricle and dentate gyrus in the hippocampus, but also some research suggest that exercise can affect prefrontal cortex (Verburgh, Königs, Scherder, \& Oosterlaan, 2014). The subventricular zone is one of two regions where neurogenesis persists in the postnatal brain. The subventricular zone, located along the lateral ventricle, is the largest neurogenic zone in the brain that contains multiple cell populations including astrocyte-like cells and neuroblasts (Lacar, Young, Platel, \& Bordey, 2010). Hippocampal dentate gyrus is another location where neurogenesis induced by physical exercise can occur. Studies carried out on animals shown that exercise causes specific granule cells in the dentate gyrus with longer and more complex dendritic arborizations in comparison to control animals which were not subject to exercise (Arida, Scorza, da Silva, Scorza, \& Cavalheiro, 2004). The third part of the brain that can be affected by exercising is the prefrontal cortex. Prefrontal 
cortex is the part of the brain located in the most frontal part of the brain lobe and makes about 10 percent of the total brain volume (Murray, Wise, \& Graham, 2017). The functions of the prefrontal cortex are numerous, but the executive function of this part is the most dominant (Koechlin, Basso, Pietrini, Panzer, \& Grafman, 1999; Wharton, \& Grafman, 1998). Different authors define executive function in a different way but generally all definitions emphasize control of short-sighted, reflexive behaviors in decision making, planning, solving some problems, dealing with some long-term aims, self-control, and attributes this functions to the region of prefrontal cortex (Koechlin, Basso, Pietrini, Panzer, \& Grafman, 1999). Prefrontal cortex is considered as the part of the brain important for the ability to learn. Each new input will be processed in prefrontal cortex before making the final decision (Spitzer, \& Hollmann, 2013).

The first studies of changes in brain structure and its function were performed on animals, mainly rodents, but in the last decade there have been plenty of researches carried out on humans proving the positive effects of exercise on the human brain too. The interest of scientists about the relation of exercise and brain functions date back to the second half of 20th century but the application of contemporary diagnostic methods of structural and functional changes in brain gave new quality to the research of this relationship. The pioneer researches were inspired by a strong desire to preserve the brain functions of elderly, aiming to find the most effective tool in fight against the brain diseases related to the loss of memory such as Alzheimer and sclerosis (Radak et al., 2010). Their findings confirm that exercise can reduce the risk of various neurological diseases and protect the brain from detrimental factors of aging and cognitive decline (Bherer, 2015). Studies that compare the cognitive performance between younger and older participants observed reduced cognitive capacities in older, but the difference were lesser if the older participants were fitter, especially if they possess higher level of cardiorespiratory fitness (Hillman, Weiss, Hagberg, \& Hatfield, 2002; Renaud, Bherer, \& Maquestiaux, 2010). Longitudinal studies carried out on the older participants reported that persons who participated in any type of regular exercise showed less cognitive decline especially when they exercise vigorously more than once a week (Barnes, Yaffe, Satariano, \& Tager, 2003; Aichberger et al., 2010).

The aim of this study is to reveal the effects of exercise on the brain structure and function in children, and to analyze methodological approach applied in the researches of this topic. There is an increasing number of researches that prove positive effects of exercise on the cognition of children and their academic achievements and a need for a comprehensive review of published scientific literature is necessary to support this relatively new line of studies. 


\section{DISCUSSION}

\section{Exercise and White Matter}

The majority of researches are performed as cross-sectional studies based on the exploring correlation between the level of physical activity and the characteristics of brain structure and function. The study results indicate that exercise has positive correlation with improved cognition and beneficial changes to brain function in children (Lees \& Hopkins, 2013). Physically active children have greater white matter integrity in several white matter tracts (corpus callosum, corona radiata, and superior longitudinal fasciculus), they have greater volume of gray matter in the hippocampus and basal ganglia than their physically inactive counterparts (Erickson, Hillman, \& Kramer, 2015; Chaddock et al., 2010b). Corpus callosum is the primary connection between the hemispheres and with more than 190 million axons is the largest white matter tract (Muetzel et al., 2008). The role of corpus callosum is integration of sensory, motor and cognitive processes between hemispheres (Hinkley et al., 2012). Underdeveloped corpus callosum is related to low cognitive function and intelligence, processing speed and problem-solving abilities, even to autism and similar syndromes (van Eimeren, Niogi, McCandliss, Holloway, \& Ansari, 2008). Physical activity and exercise lead to increased white matter microstructure of corpus callosum in children (Chaddock-Heyman et al., 2018). Scientists explain that this increase is caused by the exercise which causes more tightly bundled and structurally compact fibers, and increased myelination (Chaddock-Heyman et al., 2018). These results have been obtained from a study including 7to 9-year-old children who were involved in after-school physical activity programme based on moderate to vigorous physical activities 5 days per week for 9 months.

\section{Importance of Duration and Intensity of Exercise for Changes in Brain Structure and Function}

The longitudinal/interventional studies also showed that exercise, mainly aerobic, improves cognitive performance of children and causes changes observed on functional magnetic resonance imaging scans (fMRI) located in prefrontal and parietal regions (Li et al., 2014). Positive changes in brain structure and function are highly dependent on the intensity and duration of exercise. Some studies support the fact that cognitive functioning can be improved with short periods of physical exercise (Hancock \& McNaughton, 1986) but many other studies did not find such effects (Cian, Barraud, Melin, \& Raphel, 2001; Isaacs \& Pohlman, 1991). Short and very intensive exercise with duration not longer than 10 minutes cannot initiate any change in perception, sensory integration or visual discrimination (Fleury, Bard, Jobin, \& Carrière, 1981), but physical exercise of moderate intensity and duration can improve significantly brain functions of children. The recommendations of researchers for exercise that can have the highest positive effects on the structure and function of brain are 20 to 40 minutes 
with sub-maximal intensity i.e. heart rate of about 60 to $70 \%$ of maximum (Ellemberg \& St-Louis-Deschênes, 2010). A study from 1979 (Gabbard \& Barton, 1979) found that children improved their mathematical skills on test only after 50 minutes of physical activity and not after 20,30 or 40 minutes. However, one of the newer studies shows benefits of cognitive functions even after 30 minutes of activities (Ellemberg \& StLouis-Deschênes, 2010).

\section{Influence of Exercise on Brain Blood Supply and Angiogenesis}

Some of the oldest explanations regarding the improvement of brain functions and structure as a consequence of exercise were based on the improvement of brain blood supply through improved blood circulation. Exercise stimulates the process of angiogenesis and the development of vascular network within the brain. This development leads to a significant improvement of oxygen concentration and a better supply of other important neurochemical substances that improve cognition. Physical activity increases perfusion, and angiogenesis directly increases the perfusion of the brain which is a good foundation for facilitating neuroplasticity and branching neural networks and synaptic connections (Konopka, 2015). This completely rational explanation is based on augmentation of the level of serotonin, dopamine and norepinephrine after the exercise (Querido \& Sheel, 2007; Vaynman \& Gomez-Pinilla, 2005). Serotonin is associated with memory storage and retrieval, and dopamine and norepinephrine with attention. The stated increase of the level of the cathecholamines that improve cognitive performances can be initiated by exercise.

\section{Influence of Age and Maturity on the Brain Changes Caused by Exercise}

Researches considering the difference of effects of exercise on brain structure and function dependent on the age and maturity of children show that the greatest influence can be achieved in the age ranges of 4-7 and 11-13 years, compared with the age ranges of 8-10 and 14-18 years (Sibley \& Etnier, 2003). Those are the periods of the intensive growth and development of children and are considered as sensitive periods that "open the gates" for a greater influence of exercise on brain, even the possibility of positive effects of exercise across the whole lifespan are absolutely confirmed (Hillman et al., 2008).

Development of the brain imaging techniques (Electroencephalography - EEG, Positron emission tomography - PET, Magnetic resonance imaging - MRI, Functional magnetic resonance imaging - fMRI) ensured the possibility to determine the changes caused by exercise within the specific regions of the brain and to locate the most intensive changes. Researches that follow a positive deflection in a stimulus-locked event-related potential (ERP) that reflects the changes in the neural representation of the stimulus environment and to the amount of attention that is required to encode a given 
stimulus (amplitude) as well as the speed of stimulus evaluation (latency) has shown changes generated by a network of neural structures in frontal lobe, the anterior cingulate cortex, infero-temporal lobe and the parietal cortex (Hillman et al., 2008). These regions of brain are highly activated in cognitive operations and processing stimulus, as well as in memorizing. Physical activity has a strong influence on spectral frequency activation, especially on P3 component of the event-related potential (ERP). The registered changes in P3 component of ERP could be explained by the changes in network of neural structures within the frontal lobe, anterior cingulate cortex, infero-temporal lobe and the parietal cortex. Larger amplitude and shorter latency of positive deflection in a P3 stimulus-locked event-related potential (ERP) are observed across a variety of intellectual tasks in participants with higher aerobic performances (Li et al., 2014). This research proves the positive relationship between higher level of physical activity or aerobic fitness and cognitive processing (Polich, 2004). Greater amount of physical activity directed towards the aerobic fitness development is beneficial for faster cognitive processing. These evidences could be important for raising smarter children. Researhes that involve MRI as a technique of tracking the changes of brain structures by imaging showed that higher levels of fitness and fitness improvement are related to larger volumes of prefrontal and temporal grey matter, as well as anterior white matter, which are the structures highly related to the intelectual performances (Chaddock-Heyman et al., 2018).

\section{Exercise and Neurogenesis}

For decades it has been thought that nerve cells can be produced exclusively during the embryonic period and early childhood, however, it is still unclear whether this is true, even more so, numerous researches have been performed in recent decades that support the hypothesis that neurogenesis is possible even in the adulthood (Cameron \& McKay, 2001). The process of neurogenesis produces thousands of new neurons every day (Cameron \& McKay, 2001). Most of these new neural cells are produced in the hippocampal formation which is highly responsive to the physical training and exercise (Curlik \& Shors, 2013; Chaddock et al., 2010a; Khan \& Hillman, 2014). One of the most influential external factors is aerobic exercise because it causes a large increase in the number of cells that are produced. This effect was revealed in the research dating from 1999 (van Praag, Kempermann, \& Gage, 1999) when the authors applied two weeks of daily voluntary exercise which caused an increase in the number of new cells by fifty percent with the greater increase in the dentate gyrus. Steiner, Murphy, McClellan, Carmichael, and Davis (2011) reported that just one day of exercise can lead to a significant increase of the number of cells produced.

Meta-analysis of McMorris \& Hale (2012) explained the influence of different exercise intensities (low, moderate, heavy) on cognitive performance. The authors of this study also monitored three moderator variables such as the timing of testing (during vs. post exercise), task complexity (central executive task vs. recall and attention/alertness 
tasks), and protocol issue, the use of counterbalancing/randomization of testing (counterbalanced/random testing vs. pre-exercise testing followed by during or post-exercise testing). The need for monitoring the time of testing is drawn from the hypothesis of catecholamines realization which occurs during, and even immediately before the exercise when hypothalamus and brainstem initiate the reaction of the sympathoadrenal system. This reaction realizes the catecholamines at the postganglionic cells of those neurons that require activating or inhibiting. With an increase of the intensity of exercise there is also epinephrine and norepinephrine are released in lesser quantity. The realized hormones catecholamines, dopamine and norepinephrine have an important role in brain functioning activating primary motor cortex, premotor cortex and supplementary motor area during exercise (McMorris \& Hale, 2012). The increases of brain concentrations of catecholamines during and following a moderate intensity exercise should facilitate cognition. With increases of intensity of exercise, the quantity of the realized catecholamines increase and lead to neural noise which could inhibit performance (Arnsten \& Goldman-Rakic, 1985).

\section{Exercise and Brain Growth Factors}

Another possible influence of exercise on brain is related to the increased concentrations of the brain-derived neurotrophic factor (BDNF) (Ferris, Williams, \& Shen, 2007; Goekint et al., 2008; Tang, Chu, Hui, Helmeste, \& Law, 2008), insulin-like growth factor 1 (IGF-1) and vascular endothelial-derived growth factor (VEGF). These three growth factors belong to the group of neurotrophins that are important for the development and maintenance of neural cells in the brain. BDNF is the major mediator of the impact of aerobic exercise on hippocampal neuroplasticity and functioning (Cotman, Berchtold, \& Christie, 2007). Effects of exercise on learning is mostly regulated by IGF-1 and BDNF. The stimulation of angiogenesis and hippocampal neurogenesis caused by exercise is regulated by IGF-1 and VEGF (Cotman et al., 2007). One of the recent studies shows that BDNF is crucial for hippocampal function, synaptic plasticity, learning and modulation of depression (Kuipers \& Bramham, 2006). The level of BDNF in different regions of brain can increase by exercise. The greatest increase of BDNF occurs in the hippocampus, and after a few days of regular exercise BDNF production is increased in all hippocampal subfields. This increase of BDNF can be maintained for weeks with regular exercising (Berchtold, Chinn, Chou, Kesslak, \& Cotman, 2005). Similar to the increase of BDNF, exercise can influence the increase of IGF-1 in hippocampal neurons and this level can last several days after the exercise. Exercise induces a rapid increase of peripheral circulating levels of IGF-1 which is the key factor of exercise-induced neurogenesis and improved memory (Trejo, Carro, \& Torres-Aleman, 2001; Ding, Vaynman, Akhavan, Ying, \& Gomez-Pinilla, 2006). Some studies consider BDNF and IGF-1 as exercise-induced mediator that has the main impact on behavioral improvements, while the exercise-induced neurogenesis and angiogenesis are regulated predominantly by mutual influence of IGF-1 and vascular endothelial-de- 
rived growth factor (VEGF). These two growth factors increase their levels by exercise in the periphery and cross the blood-brain barrier to enter the brain (Trejo et al., 2001; Fabel et al., 2003; Lopez-Lopez, LeRoith, \& Torres-Aleman, 2004).

\section{CONCLUSION}

The examined researches undoubtedly proved that exercise can make positive changes of the brain structures in children, specifically the volume of the hippocampus which is the center of learning and memory. Changes are also associated with greater dorsal striatum volumes and these changes lead to a better cognitive control. Comprehensively observed, the influence of exercise on brain can be described on molecular, cellular, behavioral and systems level. The researches conducted to date do not give a completely clear picture of the necessary volume and intensity of exercise, as well as the type of exercise that can induce the greatest effect on the brain in children. The researchers could agree that the most influential type of exercise on the changes of brain structure and functions are aerobic exercises, especially if performing they require some cognitive deliberation and a higher level of attention. Such exercises can lead to a greater volume of parts of the brain responsible for memory and process of thinking in children which all together leads to a successful raising of smarter children. Also, the recommended duration of such aerobic exercise is between 20 and 40 minutes. Further randomized control studies are necessary to discover the influences of different types of exercise and different intensities and volumes of exercise on brain structure and function.

\section{REFERENCES}

Aichberger, M. C., Busch, M. A., Reischies, F. M., Ströhle, A., Heinz, A., \& Rapp, M. A. (2010). Effect of physical inactivity on cognitive performance after 2.5 years of followup. GeroPsych. 23(1), 7-15. https://doi.org/10.1024/1662-9647/a000003.

Arida, R. M., Scorza, C. A., da Silva, A. V., Scorza, F. A., \& Cavalheiro, E. A. (2004). Differential effects of spontaneous versus forced exercise in rats on the staining of parvalbumin-positive neurons in the hippocampal formation. Neuroscience Letters, 364(3), 135-138. https://doi.org/10.1016/j.neulet.2004.03.086.

Arnsten, A. F. T., \& Goldman-Rakic, P. S. (1985). Alpha 2-adrenergic mechanisms in prefrontal cortex associated with cognitive decline in aged nonhuman primates. Science, 230(4731), 1273-1276. https://doi.org/10.1126/science.2999977.

Barnes, D. E., Yaffe, K., Satariano, W. A., \& Tager, I. B. (2003). A longitudinal study of cardiorespiratory fitness and cognitive function in healthy older adults. Journal of the American Geriatrics Society, 51(4), 459-465. https://doi.org/10.1046/j.15325415.2003.51153.x.

Berchtold, N. C., Chinn, G., Chou, M., Kesslak, J. P., \& Cotman, C. W. (2005). Exercise primes a molecular memory for brain-derived neurotrophic factor protein induction in 
the rat hippocampus. Neuroscience, 133(3), 853-861. https://doi.org/10.1016/j.neuroscience.2005.03.026.

Bherer, L. (2015). Cognitive plasticity in older adults: effects of cognitive training and physical exercise. Annals of the New York Academy of Sciences, 1337(1), 1-6. https:// doi.org/10.1111/nyas.12682.

Cameron, H. A., \& McKay, R. D., (2001). Adult neurogenesis produces a large pool of new granule cells in the dentate gyrus. The Journal of Comparative Neurology 435(4), 406-417. https://doi.org/10.1002/cne.1040.

Chaddock, L., Erickson, K. I., Prakash, R. S., Kim, J. S., Voss, M. W., VanPatter, M., ... \& Cohen, N. J. (2010a). A neuroimaging investigation of the association between aerobic fitness, hippocampal volume, and memory performance in preadolescent children. Brain Research, 1358, 172-183. https://doi.org/10.1016/j.brainres.2010.08.049.

Chaddock, L., Erickson, K. I., Prakash, R. S., VanPatter, M., Voss, M. W., Pontifex, M. B., ... \& Kramer, A. F. (2010b). Basal ganglia volume is associated with aerobic fitness in preadolescent children. Developmental Neuroscience, 32(3), 249-256. https:// doi.org/10.1159/000316648.

Chaddock, L., Pontifex, M. B., Hillman, C. H., \& Kramer, A. F. (2011). A review of the relation of aerobic fitness and physical activity to brain structure and function in children. Journal of the international Neuropsychological Society, 17(6), 975-985. https:// doi.org/10.1017/S1355617711000567.

Chaddock-Heyman, L., Erickson, K. I., Kienzler, C., Drollette, E., Raine, L., Kao, S. C., ... \& Kramer, A. (2018). Physical activity increases white matter microstructure in children. Frontiers in Neuroscience, 12, 950. https://doi.org/10.3389/fnins.2018.00950.

Cian, C., Barraud, P. A., Melin, B., \& Raphel, C. (2001). Effects of fluid ingestion on cognitive function after heat stress or exercise-induced dehydration. International Journal of Psychophysiology, 42(3), 243-251. https://doi.org/10.1016/S0167-8760(01)00142-8.

Cotman, C. W., Berchtold, N. C., \& Christie, L. A. (2007). Exercise builds brain health: key roles of growth factor cascades and inflammation. Trends in Neurosciences, 30(9), 464-472. https://doi.org/10.1016/j.tins.2007.06.011.

Curlik, D. M., \& Shors, T. J. (2013). Training your brain: do mental and physical (MAP) training enhance cognition through the process of neurogenesis in the hippocampus? Neuropharmacology, 64, 506-514. https://doi.org/10.1016/j.neuropharm.2012.07.027.

Ding, Q., Vaynman, S., Akhavan, M., Ying, Z., \& Gomez-Pinilla, F. (2006). Insulinlike growth factor I interfaces with brain-derived neurotrophic factor-mediated synaptic plasticity to modulate aspects of exercise-induced cognitive function. Neuroscience, 140(3), 823-833. https://doi.org/10.1016/j.neuroscience.2006.02.084.

Ellemberg, D., \& St-Louis-Deschênes, M. (2010). The effect of acute physical exercise on cognitive function during development. Psychology of Sport and Exercise, 11(2), 122126. https://doi.org/10.1016/j.psychsport.2009.09.006.

Erickson, K. I., Hillman, C. H., \& Kramer, A. F. (2015). Physical activity, brain, and cognition. Current Opinion in Behavioral Sciences, 4, 27-32. https://doi.org/10.1016/j. cobeha.2015.01.005.

Fabel, K., Fabel, K., Tam, B., Kaufer, D., Baiker, A., Simmons, N., ... \& Palmer, T. D. (2003). VEGF is necessary for exercise-induced adult hippocampal neurogenesis. European Journal of Neuroscience, 18(10), 2803-2812. https://doi.org/10.1111/j.14609568.2003.03041.x. 
Ferris, L. T., Williams, J. S., \& Shen, C. L. (2007). The effect of acute exercise on serum brain-derived neurotrophic factor levels and cognitive function. Medicine and Science in Sports and Exercise, 39(4), 728. https://doi.org/10.1249/mss.0b013e31802f04c7.

Fleury, M., Bard, C., Jobin, J., \& Carrière, L. (1981). Influence of different types of physical fatigue on a visual detection task. Perceptual and Motor Skills, 53(3), 723-730. https://doi.org/10.2466/pms.1981.53.3.723.

Gabbard, C., \& Barton, J. (1979). Effects of physical activity on mathematical computation among young children. Journal of Psychology, 103, 287-88.

Goekint, M., Heyman, E., Roelands, B., Njemini, R., Bautmans, I., Mets, T., \& Meeusen, R. (2008). No influence of noradrenaline manipulation on acute exercise-induced increase of brain-derived neurotrophic factor. Medicine and Science in Sports and Exercise, 40(11), 1990-1996. https://doi.org/10.1249/MSS.0b013e31817eee85.

Hancock, S., \& McNaughton, L. (1986). Effects of fatigue on ability to process visual information by experienced orienteers. Perceptual and Motor Skills, 62(2), 491-498. https://doi.org/10.2466/pms.1986.62.2.491.

Hillman, C. H., Erickson, K. I., \& Kramer, A. F. (2008). Be smart, exercise your heart: exercise effects on brain and cognition. Nature Reviews Neuroscience, 9(1), 58. https:// doi.org/10.1038/nrn2298.

Hillman, C. H., Pontifex, M. B., Raine, L. B., Castelli, D. M., Hall, E. E., \& Kramer, A. F. (2009). The effect of acute treadmill walking on cognitive control and academic achievement in preadolescent children. Neuroscience, 159(3), 1044-1054. https://doi. org/10.1016/j.neuroscience.2009.01.057.

Hillman, C. H., Weiss, E. P., Hagberg, J. M., \& Hatfield, B. D. (2002). The relationship of age and cardiovascular fitness to cognitive and motor processes. Psychophysiology, 39(3), 303-312. https://doi.org/10.1017/S0048577201393058.

Hinkley, L. B., Marco, E. J., Findlay, A. M., Honma, S., Jeremy, R. J., Strominger, Z., ... \& Barkovich, A. J. (2012). The role of corpus callosum development in functional connectivity and cognitive processing. PLoS One, 7(8), e39804. https://doi.org/10.1371/ journal.pone.0039804

Isaacs, L. D., \& PohIman, E. L. (1991). Effects of exercise intensity on an accompanying timing task. Journal of Human Movement Studies, 20, 123-131.

Khan, N. A., \& Hillman, C. H. (2014). The relation of childhood physical activity and aerobic fitness to brain function and cognition: a review. Pediatric Exercise Science, 26(2), 138-146. https://doi.org/10.1123/pes.2013-0125.

Kobilo, T., Liu, Q. R., Gandhi, K., Mughal, M., Shaham, Y., \& van Praag, H. (2011). Running is the neurogenic and neurotrophic stimulus in environmental enrichment. Learning \& Memory, 18(9), 605-609. https://doi.org/10.1101/lm.2283011.

Koechlin, E., Basso, G., Pietrini, P., Panzer, S., \& Grafman, J. (1999). The role of the anterior prefrontal cortex in human cognition. Nature, 399(6732), 148-151. https://doi. org/10.1038/20178.

Konopka, L. M. (2015). How exercise influences the brain: a neuroscience perspective. Croatian Medical Journal, 56(2), 169. https://doi.org/10.3325/cmj.2015.56.169.

Kuipers, S. D. \& Bramham, C. R. (2006). Brain-derived neurotrophic factor mechanisms and function in adult synaptic plasticity: new insights and implications for therapy. Current Opinion in Drug Discovery \& Development, 9(5), 580-586. 
Lacar, B., Young, S. Z., Platel, J. C., \& Bordey, A. (2010). Imaging and recording subventricular zone progenitor cells in live tissue of postnatal mice. Frontiers in Neuroscience, 4, 43. https://doi.org/10.3389/fnins.2010.00043.

Lees, C., \& Hopkins, J. (2013). Effect of aerobic exercise on cognition, academic achievement, and psychosocial function in children: a systematic review of randomized control trials. Preventing Chronic Disease, 10. https://doi.org/10.5888/pcd10.130010.

Li, L., Men, W. W., Chang, Y. K., Fan, M. X., Ji, L., \& Wei, G. X. (2014). Acute aerobic exercise increases cortical activity during working memory: a functional MRI study in female college students. PloS one, 9(6), e99222. https://doi.org/10.1371/journal. pone.0099222.

Lopez-Lopez, C., LeRoith, D., \& Torres-Aleman, I. (2004). Insulin-like growth factor I is required for vessel remodeling in the adult brain. Proceedings of the National Academy of Sciences, 101(26), 9833-9838. https://doi.org/10.1073/pnas.0400337101.

McMorris, T., \& Hale, B. J. (2012). Differential effects of differing intensities of acute exercise on speed and accuracy of cognition: a meta-analytical investigation. Brain and Cognition, 80(3), 338-351. https://doi.org/10.1016/j.bandc.2012.09.001.

Muetzel, R. L., Collins, P. F., Mueller, B. A., Schissel, A. M., Lim, K. O., \& Luciana, M. (2008). The development of corpus callosum microstructure and associations with bimanual task performance in healthy adolescents. Neuroimage, 39(4), 1918-1925. https://doi.org/10.1016/j.neuroimage.2007.10.018.

Mundkur, N. (2005). Neuroplasticity in children. The Indian Journal of Pediatrics, 72(10), 855-857. https://doi.org/10.1007/BF02731115.

Murray, E. A., Wise, S. P., \& Graham, K. S. (2017). The evolution of memory systems: ancestors, anatomy, and adaptations. Oxford University Press.

Myer, G. D., Faigenbaum, A. D., Edwards, N. M., Clark, J. F., Best, T. M., \& Sallis, R. E. (2015). Sixty minutes of what? A developing brain perspective for activating children with an integrative exercise approach. British Journal of Sports Medicine, 49(23), 15101516. https://doi.org/10.1136/bjsports-2014-093661.

Polich, J. (2004). Clinical application of the P300 event-related brain potential. Physical Medicine and Rehabilitation Clinics, 15(1), 133-161. https://doi.org/10.1016/S10479651(03)00109-8.

Querido, J. S., \& Sheel, A. W. (2007). Regulation of cerebral blood flow during exercise. Sports Medicine, 37(9), 765-782. https://doi.org/10.2165/00007256-200737090-00002.

Radak, Z., Hart, N., Sarga, L., Koltai, E., Atalay, M., Ohno, H., \& Boldogh, I. (2010). Exercise plays a preventive role against Alzheimer's disease. Journal of Alzheimer's Disease, 20(3), 777-783. https://doi.org/10.3233/JAD-2010-091531.

Renaud, M., Bherer, L., \& Maquestiaux, F. (2010). A high level of physical fitness is associated with more efficient response preparation in older adults. Journals of Gerontology Series B: Psychological Sciences and Social Sciences, 65(3), 317-322. https://doi. org/10.1093/geronb/gbq004.

Sibley, B. A., \& Etnier, J. L. (2003). The relationship between physical activity and cognition in children: a meta-analysis. Pediatric Exercise Science, 15(3), 243-256. https://doi. org/10.1123/pes.15.3.243.

Spitzer, U. S., \& Hollmann, W. (2013). Experimental observations of the effects of physical exercise on attention, academic and prosocial performance in school settings. Trends in Neuroscience and Education, 2(1), 1-6. https://doi.org/10.1016/j.tine.2013.03.002. 
Steiner, J. L., Murphy, E. A., McClellan, J. L., Carmichael, M. D., \& Davis, J. M. (2011). Exercise training increases mitochondrial biogenesis in the brain. Journal of Applied Physiology, 111(4), 1066-1071. https://doi.org/10.1152/japplphysiol.00343.2011.

Tang, S. W., Chu, E., Hui, T., Helmeste, D., \& Law, C. (2008). Influence of exercise on serum brain-derived neurotrophic factor concentrations in healthy human subjects. Neuroscience Letters, 431(1), 62-65. https://doi.org/10.1016/j.neulet.2007.11.019.

Tomporowski, P. D., McCullick, B., Pendleton, D. M., \& Pesce, C. (2015). Exercise and children's cognition: the role of exercise characteristics and a place for metacognition. Journal of Sport and Health Science, 4(1), 47-55. https://doi.org/10.1016/j. jshs.2014.09.003.

Trejo, J. L., Carro, E., \& Torres-Aleman, I. (2001). Circulating insulin-like growth factor I mediates exercise-induced increases in the number of new neurons in the adult hippocampus. Journal of Neuroscience, 21(5), 1628-1634. https://doi.org/10.1523/JNEUROSCI.21-05-01628.2001.

van Eimeren, L., Niogi, S. N., McCandliss, B. D., Holloway, I. D., \& Ansari, D. (2008). White matter microstructures underlying mathematical abilities in children. Neuroreport, 19(11), 1117-1121. https://doi.org/10.1097/WNR.0b013e328307f5c1.

van Praag, H., Kempermann, G., Gage, F. H., (1999). Running increases cell proliferation and neurogenesis in the adult mouse dentate gyrus. Nature Neuroscience, 2(3), 266-270. https://doi.org/10.1038/6368.

Vaynman, S., \& Gomez-Pinilla, F. (2005). License to run: exercise impacts functional plasticity in the intact and injured central nervous system by using neurotrophins. Neurorehabilitation and Neural Repair, 19(4), 283-295. https://doi.org/10.1177/1545968305280753.

Verburgh, L., Königs, M., Scherder, E. J., \& Oosterlaan, J. (2014). Physical exercise and executive functions in preadolescent children, adolescents and young adults: a meta-analysis. British Journal of Sports Medicine, 48(12), 973-979. https://doi.org/10.1136/ bjsports-2012-091441.

Wharton, C. \& Grafman, J. (1998). Reasoning and the human brain. Trends in Cognitive Sciences, 2(2), 54-59. https://doi.org/10.1016/S1364-6613(98)01122-X. 